\title{
Photosynthetic pigments, cell extrusion and relative leaf water content of the castor bean under silicon and salinity
}

\author{
Rener L. de S. Ferraz ${ }^{1}$, Ivomberg D. Magalhães ${ }^{1}$, Napoleão E. de M. Beltrão ${ }^{2}$, \\ Alberto S. de Melo $^{3}$, Jósé F. de Brito Neto ${ }^{4} \&$ Maria do S. Rocha ${ }^{5}$

\footnotetext{
${ }^{1}$ Programa de Pós-graduação em Ciências Agrárias/Universidade Estadual da Paraíba/Embrapa Algodão. Campina Grande, PB. E-mail: ferraz340@gmail.com; ivomberg31@hotmail.com

${ }^{2}$ Embrapa Algodão. Campina Grande, PB. (In memoriam)

${ }^{3}$ Departamento de Biologia/Centro de Ciências Biológicas e da Saúde/Universidade Estadual da Paraíba. Campina Grande, PB. E-mail: alberto@uepb.edu.br (Autor correspondente)

${ }^{4}$ Departamento de Agroecologia/Centro de Ciências Agrárias e Ambientais/Universidade Estadual da Paraíba. Lagoa Seca, PB. E-mail: jose.felix@embrapa.br ${ }^{5}$ Programa de Pós-graduação em Ciências Agrárias/Universidade Estadual da Paraíba. Campina Grande, PB. E-mail: marialirium@hotmail.com (Bolsista PNPD CAPES)
}

\section{Key words:}

Ricinus communis L.

chlorophyll

electrolyte leakage

electrical conductivity

leaf fertilization

\begin{abstract}
A B S T R A C T
The castor bean crop plays an important social, environmental and economic role, especially due to possibility of its use as feedstock for the generation of clean energy. Thus, this study aimed to evaluate the contents of photosynthetic pigments, cell membrane extrusion and the relative water content in the leaves of the castor bean cultivar 'BRS Energia' under silicon and salinity levels. The experiment was carried out at Embrapa Cotton, in a completely randomized design, in a $4 \times 4$ factorial scheme, and the treatments consisted of four silicon levels $\left(0,100,200\right.$ and $\left.300 \mathrm{mg} \mathrm{L}^{-1}\right)$ and four water salinity levels of (ECw 0, 2, 4 and $\left.6 \mathrm{dS} \mathrm{m}^{-1}\right)$, with three replicates. The gradual increase in salinity levels reduced the concentration of photosynthetic pigments, relative water content in the leaves and increased cell membrane extrusion. The increase in the concentration of silicon reduced the harmful effects of salts on the analysed variables in the castor bean 'BRS Energia'.
\end{abstract}

\section{Palavras-chave:}

Ricinus communis L.

clorofila

extravasamento de eletrólitos

condutividade elétrica

adubação foliar

\section{Pigmentos fotossintetizantes, extrusão celular e conteúdo relativo de água nas folhas da mamoneira sob silício e salinidade}

\footnotetext{
R E S U M O

A mamoneira desempenha importante papel socioambiental e econômico, notadamente pela possibilidade de sua utilização como matéria-prima na geração de energias limpas, razão pela qual se objetivou, com este trabalho, avaliar o teor de pigmentos fotossintetizantes, a extrusão celular e o conteúdo relativo de água nas folhas de plantas de mamoneira BRS Energia em níveis de silício e salinidade. O experimento foi conduzido na Embrapa Algodão, em delineamento experimental inteiramente casualizado, em esquema fatorial $4 \times 4$, sendo quatro níveis de silício $\left(0,100,200\right.$, e $\left.300 \mathrm{mg} \mathrm{L}^{-1}\right)$, quatro níveis de salinidade da água (CEa $0,2,4$ e $6 \mathrm{dS} \mathrm{m}^{-1}$ ) e três repetições. $\mathrm{O}$ aumento gradual nos níveis de salinidade reduziu o teor de pigmentos fotossintéticos, o conteúdo relativo de água nas folhas mas aumentou a extrusão da membrana celular. $\mathrm{O}$ aumento na concentração de silício reduziu o efeito nocivo dos sais sobre as variáveis analisadas na mamoneira 'BRS Energia'.
} 


\section{INTRODUCTION}

Castor bean (Ricinus communis L.) belongs to the Euphorbiaceae family and is characterized by its rusticity, especially due to its easy adaptation to various ecosystems (Oliveira, 2011). Given its socio-environmental and economic importance, this crop has stood out among oleaginous plants, especially with the advent of the National Biodiesel Program and the possibility of generation of renewable energy using its oil (Goneli et al., 2011).

In Brazil, castor bean is cultivated in the southeast, south and northeast (Nazareno et al., 2011), from which the northeast region stands out as the responsible for the production of $85 \%$ of the planted area, comprehending more than $78 \%$ of the national production. Castor bean is cultivated in all the states of the northeast region, except for Sergipe and Maranhão, although these states have intrinsic potentialities for its production (Oliveira, 2011).

Despite the rusticity, castor bean yield can be reduced due to the influence of biotic and abiotic factors of each ecosystem, such as nutrient availability (Costa et al., 2011) and the accumulation of salts in the soil and in the water. In this context, Fagan et al. (2009) reported that the semiarid region is characterized by irregular spatial and temporal rainfall distribution and the increase in water consumption, especially by irrigated agriculture, which can increase salt contents in the soil due to inadequate management.

High salt contents in the soil and in irrigation water, resulting from the high evaporation levels of the water bodies, notably in the Brazilian semiarid region, is a limiting factor for castor bean cultivation, especially because saline stress causes a reduction in germination, growth and production, leading to morphological, structural and metabolic changes. This effect is due to the reduction in the osmotic potential of the medium, which compromises water absorption and the processes of cell division and elongation, besides mobilizing reserves that are indispensable for plant metabolic processes (Silva et al., 2011). This scenario presents itself as a challenge for the scientific community, since new alternatives must be used in castor bean cultivation in order to mitigate the harmful effects of salts, which will allow the cultivation of castor bean in the semiarid region, including salinized environments, and avoid the deforestation of new areas.

The use of silicon ( $\mathrm{Si}$ ) through foliar application can be a viable alternative to mitigate the harmful effects of salts in plants (Lima et al., 2011). This occurs because, although Si is not considered an essential element (Giongo \& Bohnen, 2011), it can optimize some desirable physiological processes, by increasing significantly the yield of cultivated species, notably by the accumulation and polymerization of silicates in epidermal cells. This mechanism forms a cuticle-silicon double layer that substantially reduces transpiration, resulting in lower water consumption (Peixoto et al., 2011) and, therefore, higher tolerance to water scarcity, due to the osmotic effect caused by salinity.

This study aimed to evaluate the content of photosynthetic pigments, cell extrusion and relative water content in the leaves, as indirect measurements to obtain information that can be enlightening about the dynamics of salts in the castor bean cultivar 'BRS Energia' under silicon and salinity levels.

\section{Material AND Methods}

The experiment was carried out in a protected environment from May to July 2011, at the National Center for Research on Cotton of the Brazilian Agricultural Research Organization (CNPA/EMBRAPA), located in Campina Grande-PB, Brazil $\left(07^{\circ} 13^{\prime} \mathrm{S} ; 53^{\circ} 31^{\prime} \mathrm{W} ; 551 \mathrm{~m}\right)$. The climate of the region is semiarid equatorial, with mean temperature of $25^{\circ}$ and relative air humidity from 72 to $91 \%$.

During the experiment, maximum temperature $\left(\mathrm{T}_{\max }\right)$, mean temperature $\left(\mathrm{T}_{\text {mean }}\right)$, minimum temperature $\left(\mathrm{T}_{\text {min }}\right)$ and relative air humidity $\left(\mathrm{RH}_{\text {air }}\right)$ were daily quantified using a thermo-hydrograph, inside the greenhouse (Figure 1).

The experiment was set in a completely randomized design in a $4 \mathrm{x} 4$ factorial scheme, and the treatments consisted of four levels of silicon $\left(0,100,200\right.$ and $\left.300 \mathrm{mg} \mathrm{L}^{-1}\right)$ and four levels of water salinity $\left(0,2,4\right.$ and $\left.6 \mathrm{dS} \mathrm{m}^{-1}\right)$, with three replicates. Each experimental unit consisted of a 20 -L pot, made of synthetic polymeric organic material, with one plant.

The soil used as substrate, with a sandy loam texture (Santos et al., 2006), showed the following chemical characteristics: sand $=814.4$; silt $=137.9$; clay $=47.7\left(\mathrm{~g} \mathrm{~kg}^{-1}\right)$; bulk density $=$ 1.52; particle density $=2.85\left(\mathrm{~kg} \mathrm{dm}^{-3}\right)$; porosity $=46.67(\%)$; natural humidity $0.30(\%)$; available water $=1.43 \% ; \mathrm{pH}$ in water $=5.1 ; \mathrm{P}=0.3 ;\left(\mathrm{mg} \mathrm{dm}^{-3}\right), \mathrm{K}=0.5 ; \mathrm{Na}=0.4 ; \mathrm{Ca}=3.7 ; \mathrm{Mg}=6.5$; $\mathrm{Al}=5.0 ; \mathrm{H}+\mathrm{Al}=28.9 ; \mathrm{T}=40.0 ;\left(\mathrm{cmol} \mathrm{dm}_{c}^{-3}\right), \mathrm{V}=28.0(\%) ; \mathrm{MO}$ $=3.6$ and $\mathrm{N}=0.0\left(\mathrm{~g} \mathrm{~kg}^{-1}\right)$. The soil was limed using dolomitic limestone, in order to increase $\mathrm{pH}$ to close to neutrality, and remained incubated for 45 days (Sávio et al., 2011). After the soil incubation period, NPK was applied as basal fertilization (Sampaio Filho et al., 2011).

Liquid silicon was used as the source of silicon, with the following characteristics: Silicon $(\mathrm{Si})=12 \%$; Potassium $(\mathrm{K})=$ $15 \%$; Saline index $=26$; Electrical conductivity $=1.93 \mathrm{dS} \mathrm{m}^{-1}$; Density $=1.40 \mathrm{~g} \mathrm{~L}^{-1} ; \mathrm{pH}=10.96$; Physical nature $=$ fluid. $\mathrm{Si}$ concentrations were obtained through the dilution of liquid Si in distilled water.

The levels of electrical conductivity of the irrigation water (ECw) were obtained by adjusting the solution of sodium

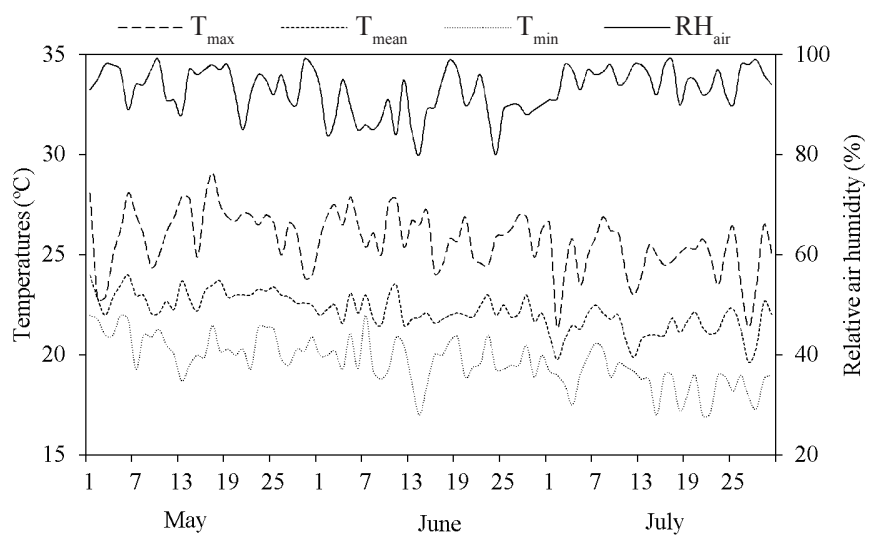

Figure 1. Maximum $\left(\mathrm{T}_{\text {max }}\right)$, mean $\left(\mathrm{T}_{\text {mean }}\right)$ and minimum $\left(\mathrm{T}_{\text {min }}\right)$ temperatures $\left({ }^{\circ} \mathrm{C}\right)$ and relative air humidity $\left(\mathrm{RH}_{\text {air }}\right)-\%$ during the experiment 
chloride $(\mathrm{NaCl})$, using a benchtop conductivity meter (MB11/ $\mathrm{MS})$. Distilled water was used for the control treatment $(\mathrm{ECw}=$ $0 \mathrm{dS} \mathrm{m} \mathrm{m}^{-1}$ ), while for the concentrations of saline water a portion of pure $\mathrm{NaCl}$ (p.a.) was diluted in water from the local water supply (Silva et al., 2011). The saline solutions were stored in 500 -L recipients and were homogenized before the application in each treatment, in order to avoid the deposition of salts at the bottom of the recipients and a consequent decrease in water electrical conductivity.

Castor bean seeds from the cultivar 'BRS Energia' came from the seed lot produced in the 2010 crop season, in the municipality of Patos - PB, and were previously treated with fungicide in order to eliminate pathogens. The water content of the substrate was close to field capacity (FC) during the seeding, which was performed by planting three seeds in each experimental unit at a depth of $3 \mathrm{~cm}$. Thinning was performed 20 days after emergence (DAE), preferentially leaving only the most vigorous plant in each experimental unit (Chaves et al., 2011).

At $25 \mathrm{DAE}$, considering this period as sufficient for plant establishment, irrigation started using the saline concentrations corresponding to the respective treatments. Evapotranspiration was replenished according to the water demand, based on the crop coefficient $(\mathrm{kc})$, through the Class-A pan method, using a graduated cylinder (Costa et al., 2011). A leaching fraction of $10 \%$ was weekly applied in order to leach the salts accumulated in the soil (Monteiro et al., 2009).

Foliar application of Si was performed by spraying the abaxial and adaxial surfaces of the castor bean leaves. For better efficiency, the surfactant $\mathrm{Du} \mathrm{Fol}^{\circ}$ was applied at the concentration of $100 \mathrm{~mL} \mathrm{~L}^{-1}$ of water in the spray solution, as recommended by the manufacturer (Sávio et al., 2011). Foliar application was performed using a 3-L pre-compression sprayer, made of high molecular weight polyethylene, with piston-type pump and a nozzle of $34 \mathrm{~mm}$ of diameter.

Part of the leaf biomass was collected 5 days after the beginning of flowering, for the determination of the following variables: contents of photosynthetic pigments, chlorophylls 'a' (Chl a), 'b' (Chl b), total chlorophyll ( Chl t) and carotenoids (Car), expressed in $\mu \mathrm{mol} \mathrm{m} \mathrm{m}^{-2}$ (Arnon, 1949; Hiscox \& Israelstam, 1979), besides cell extrusion (Ext) and relative water content in the leaves (RWC) (Brito et al., 2011).

The data were subjected to $\mathrm{F}$ test at 0.05 probability level. For the significant variables $(\mathrm{p}<0.05)$, regression analysis was performed. The mathematical model for each variable was selected based on the significance of the parameters and on the value of $\mathrm{R}^{2}$ (Santos et al., 2008). The software SAEG 9.1 was used to verify the statistical consistency of the data and the fit of the regression models.

\section{Results AND Discussion}

There was a significant effect of the treatments (Table 1 ) on the variables chlorophyll 'a' ( $\mathrm{Chl} \mathrm{a})(\mathrm{p}<0.05)$, total chlorophyll (Chl t) $(\mathrm{p}<0.05)$, cell extrusion (Ext) $(\mathrm{p}<0.01)$ and the relative water content in the leaves (RWC) $(\mathrm{p}<0.01)$. The interaction between the factors Si levels and ECw levels was significant for the variables Chl a $(\mathrm{p}<0.05)$, Chl t $(\mathrm{p}<0.05)$ and Ext $(\mathrm{p}<0.01)$.

The contents of $\mathrm{Chl}$ a showed a polynomial tendency with the increasing levels of ECw at the Si levels (Figure 2). Decreases of 23.4 and $34.7 \%$ in Chl a contents were observed in the control treatment $\left(0 \mathrm{mg} \mathrm{L}^{-1}\right)$ (Figure $\left.2 \mathrm{~A}\right)$ and at the lowest $\mathrm{Si}$ level (100 $\left.\mathrm{mg} \mathrm{L}^{-1}\right)$ (Figure $2 \mathrm{~B}$ ), respectively, and the lowest values $\left(222.56\right.$ and $172.34 \mu \mathrm{mol} \mathrm{m} \mathrm{m}^{-2}$ ) were found for the saline concentrations of 3.5 and $3.68 \mathrm{dS} \mathrm{m}^{-1}$, respectively. Nevertheless, salinity effect was alleviated with the $\mathrm{Si}$ applications of $200 \mathrm{mg} \mathrm{L}^{-1}$ (Figure 2C) and $300 \mathrm{mg} \mathrm{L}^{-1}$ (Figure $2 \mathrm{D})$, with maximum estimates of 276.36 and $275.81 \mu \mathrm{mol} \mathrm{m}{ }^{-2}$ for the ECw levels of 5.5 and $2.77 \mathrm{dS} \mathrm{m}^{-1}$, which corresponded to gains of 33.1 and $16.6 \%$, respectively, compared with the control treatment $\left(0 \mathrm{dS} \mathrm{m} \mathrm{m}^{-1}\right)$.

The lower contents of chlorophyll 'a' observed in castor bean leaves in the control $\left(0 \mathrm{mg} \mathrm{L}^{-1}\right)$ and at the lowest Si level (100 $\mathrm{mg} \mathrm{L}^{-1}$ ) are possibly associated with the effect of toxicity caused by the increase in saline concentration in the soil on plant metabolism (Marques et al., 2011). According to Silva et al. (2011), this can also be related to the osmotic effect of the stress and consequent increase in transpiration, leading to a lower photosynthetic efficiency.

The interaction of the ECw and Si levels of 200 and $300 \mathrm{mg}$ $\mathrm{L}^{-1}$ resulted in the most expressive estimates of chlorophyll 'a' (276.36 and $275.81 \mu \mathrm{mol} \mathrm{m}^{-2}$ ), probably due to the optimization of the defense mechanism developed by plants in response to $\mathrm{Si}$ application under conditions of abiotic stress, like salinity (Sávio et al., 2011).

The contents of chlorophyll 'b' suffered reductions of 37, $28.8,18.5$ and $24 \%$, respectively, with the increase in salinity at the Si levels of 0, 100, 200 and $300 \mathrm{mg} \mathrm{L}^{-1}$, respectively (Figure 3). However, it is important to notice that saline concentrations were less harmful for the contents of chlorophyll 'b' compared with chlorophyll 'a', especially at the highest Si levels. The lowest estimates $\left(38.56,41.2,43.6\right.$ and $\left.46.8 \mu \mathrm{mol} \mathrm{m}^{-2}\right)$ were obtained through the mathematical models shown in Figure 3A, B, C

Table 1. Summary of the analysis of variance for the variables chlorophyll ' $a$ ' (Chl a), chlorophyll 'b' (Chl b), total chlorophyll (Chl t), carotenoid (Car), cell extrusion (Ext) and relative water content in the leaves (RWC) of the castor bean cultivar 'BRS Energia' under levels of salinity and silicon

\begin{tabular}{|c|c|c|c|c|c|c|c|}
\hline \multirow{2}{*}{ S.V. } & \multirow{2}{*}{ D.F. } & \multicolumn{6}{|c|}{ Mean square } \\
\hline & & Chl a & Chl b & Chl t & Car & Ext & RWC \\
\hline Treatments & (15) & $4587.93^{\star}$ & $152.04^{\mathrm{ns}}$ & $6150.05^{\star}$ & $961.36^{\text {ns }}$ & $81.45^{\star \star}$ & $167.64^{* \star}$ \\
\hline Silicon (Si) & 3 & $4231.11^{\mathrm{ns}}$ & $122.31^{\text {ns }}$ & $6329.07^{\mathrm{ns}}$ & $839.80^{\text {ns }}$ & $17.79^{* *}$ & $13.51^{* *}$ \\
\hline Cond. (ECw) & 3 & $566.78^{\text {ns }}$ & $335.61^{\star}$ & $2114.34^{\mathrm{ns}}$ & $595.53^{\text {ns }}$ & $386.45^{\star \star}$ & $823.08^{\star \star}$ \\
\hline Int. Si x ECW & 9 & $6047.26^{\star}$ & $100.75^{\mathrm{ns}}$ & $7435.61^{*}$ & $1123.82^{\mathrm{ns}}$ & $1.01^{\star \star}$ & $0.53^{\text {ns }}$ \\
\hline Residue & 32 & 2144.73 & 101.50 & 2468.61 & 569.57 & 0.12 & 0.48 \\
\hline C.V (\%) & & 19.59 & 19.42 & 17.22 & 15.78 & 2.49 & 1.8 \\
\hline
\end{tabular}

S.V. - Source of variation; D.F. - Degree of freedom; ECw - Electrical conductivity; Int. - Interaction; **, *Significant at 0.01 and 0.05 respectively; nsNot significant by F test at 0.05 probability level 

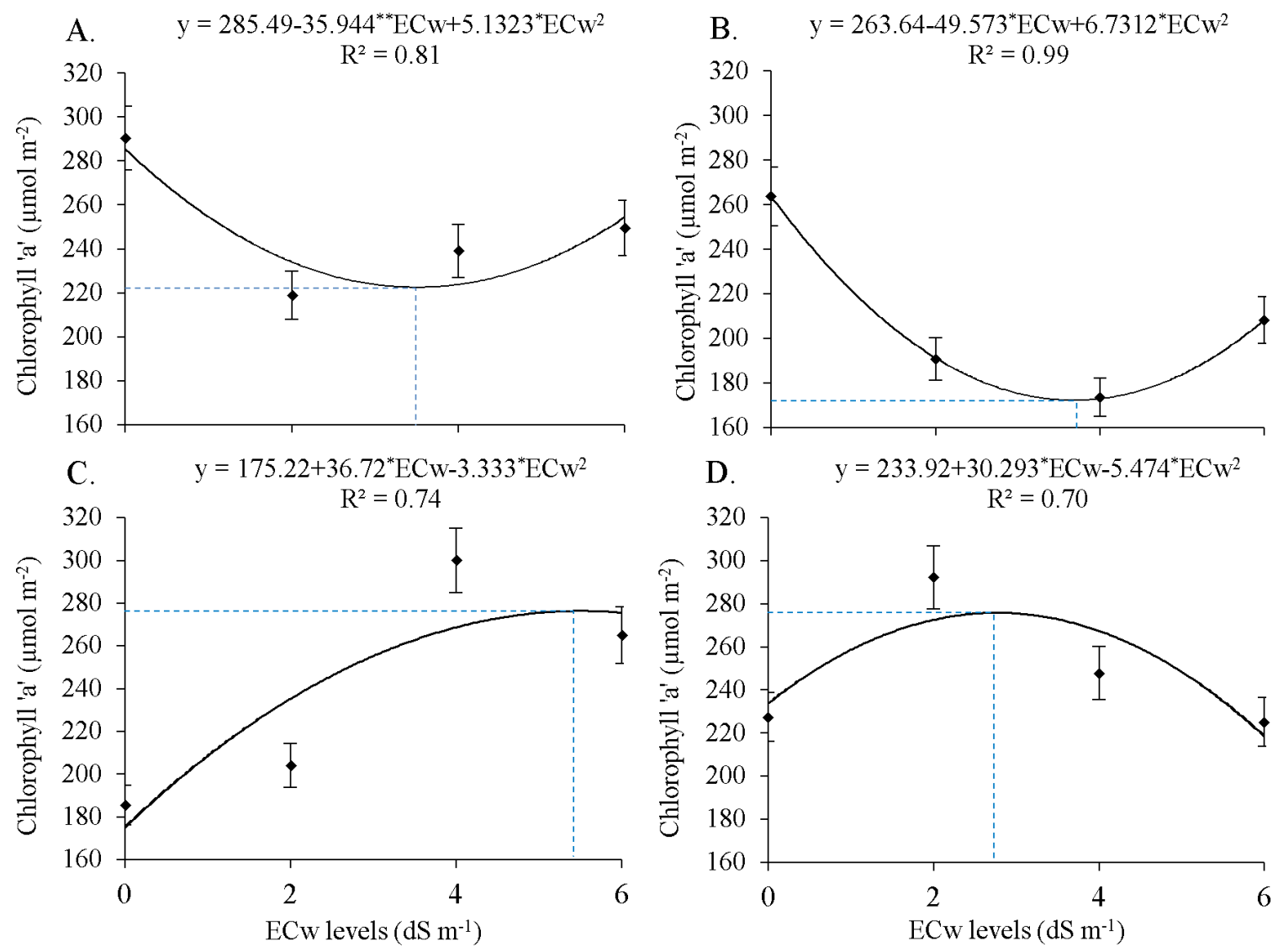

Figure 2. Effect of electrical conductivity of the irrigation water (ECW) $\left(\mathrm{dS} \mathrm{m}^{-1}\right)$ at the silicon levels of 0 (A), 100 (B), 200 (C) and $300 \mathrm{mg} \mathrm{L}^{-1}$ (D) on the content of chlorophyll ' $\mathrm{a}$ ' in leaves of the castor bean cultivar 'BRS Energia' cultivated in protected environment
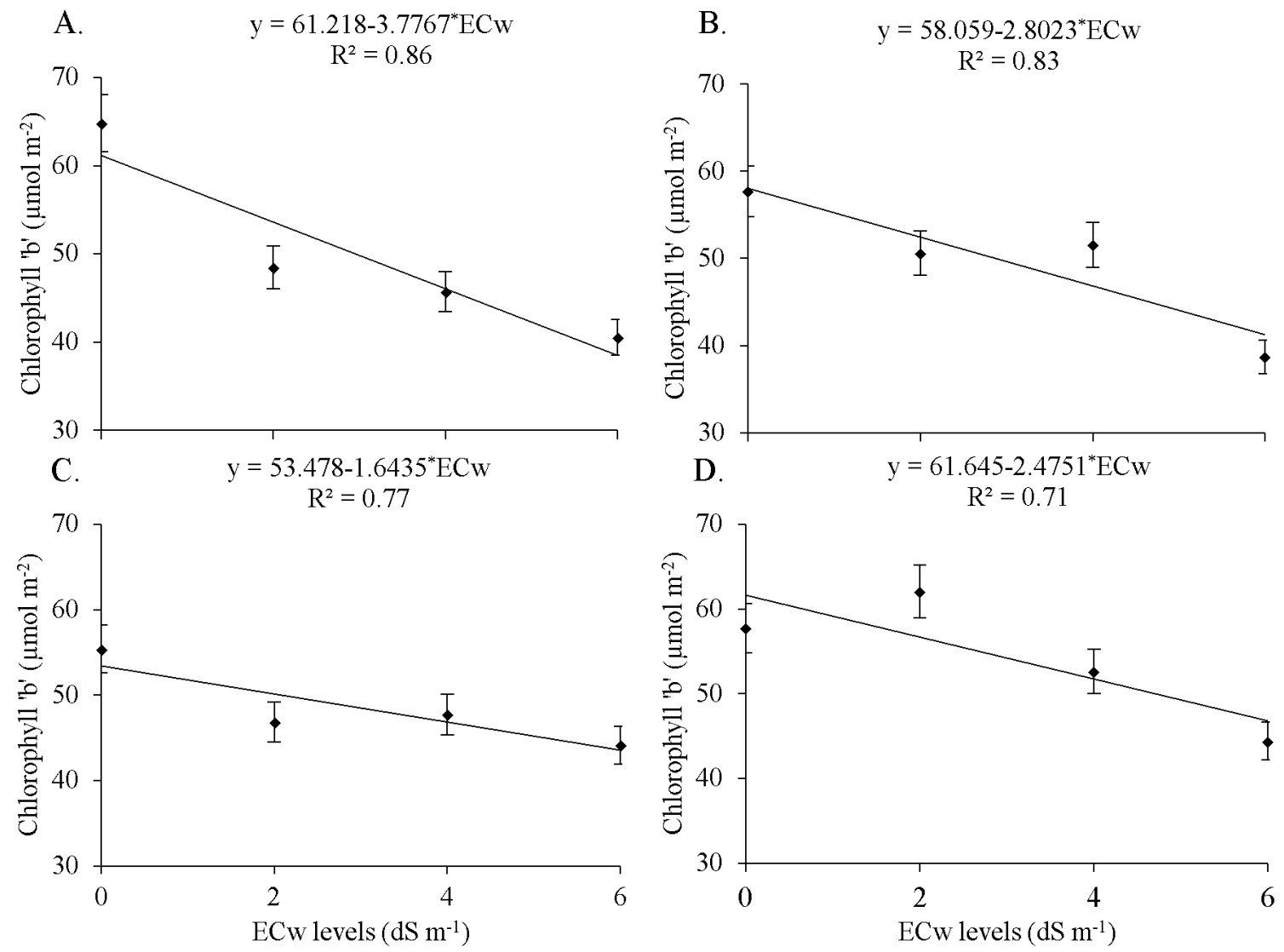

Figure 3. Effect of electrical conductivity of the irrigation water (ECW) at the silicon levels of 0 (A), 100 (B), (C) and 300 $\mathrm{mg} \mathrm{L}^{-1}(\mathrm{D})$ on the content of chlorophyll ' $b$ ' in leaves of the castor bean cultivar 'BRS Energia' cultivated in protected environment 
and $\mathrm{D}$, respectively, which were used to calculate the percent reductions previously mentioned.

The decrease in the contents of chlorophyll 'b', due to the increase in saline concentration according to Lopes \& Silva (2010) causes physiological disorders through the alteration of biochemical constituents of the plants. The decrease in the contents of chlorophyll ' $b$ ' was less in plants subjected to the highest Si levels. This can be a consequence of the beneficial effect of Si on plant metabolism, especially through the amorphous Si layer formed in epidermal cells (Lima et al., 2011), which can promote greater relief of the water deficit stress (Ávila et al., 2010) caused by the reduction of soil water potential and the accumulation of toxic ions of $\mathrm{Na}^{+}$and $\mathrm{Cl}$ (Rodrigues et al., 2013).

The contents of total chlorophyll decreased, especially in the control $\left(0 \mathrm{mg} \mathrm{L}^{-1}\right)$ (Figure $\left.4 \mathrm{~A}\right)$ and at the lowest Si level (100 $\mathrm{mg} \mathrm{L}^{-1}$ ) (Figure 4B). In addition, the lowest estimates of total chlorophyll $\left(269.77\right.$ and $\left.224.8 \mu \mathrm{mol} \mathrm{m}^{-2}\right)$ were obtained at the saline levels of 3.4 and $3.7 \mathrm{dS} \mathrm{m}^{-1}$, which corresponded to decreases in chlorophyll contents of about 22.7 and $30.8 \%$, respectively, compared with plants under control. However, as for chlorophylls 'a' and 'b', total chlorophyll contents increased gradually with the increase in Si levels $\left(200 \mathrm{mg} \mathrm{L}^{-1}\right.$ - Figure $4 \mathrm{C})$ and (300 $\mathrm{mg} \mathrm{L}^{-1}$ - Figure 4D), with estimates of 285.3 and $334.7 \mu \mathrm{mol} \mathrm{m} \mathrm{m}^{-2}$ for the saline levels of 3.21 and $2.6 \mathrm{dS} \mathrm{m}$. These gains represent 16 and $12.6 \%$ of the contents of total chlorophyll observed in the plants not subjected to irrigation with saline water.

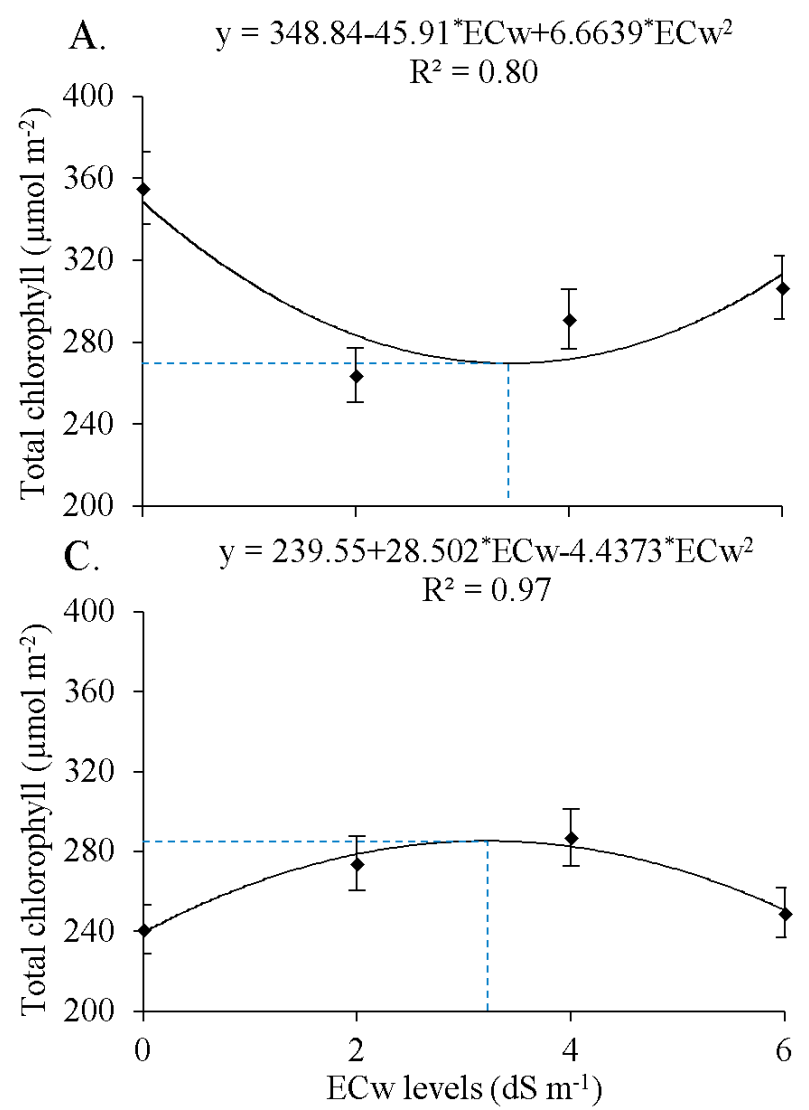

The increase in chlorophyll contents due to Si supply was also observed by Al-Aghabary et al. (2005) in tomato plants under saline stress. Ávila et al. (2010) mentioned that the increase in chlorophyll contents is probably related to the increase in $\mathrm{Si}$ in epidermal cells of the shoots, which improves the opening angle of the leaves and favors a better use of light.

The increments in salinity levels caused significant increase $(\mathrm{p}<0.01)$ in the rupture of cell membrane, observed by the increase in the percentage of leaked electrolytes (Figure 5). The highest estimates for cell extrusion $(22.81 \%$ - Figure $5 \mathrm{~A}$; $21 \%$ - Figure 5B; 19.9\% - Figure 5C; and 19.47\% - Figure $5 \mathrm{D})$ were obtained for the ECw level of $6 \mathrm{dS} \mathrm{m} \mathrm{m}^{-1}$. These values represented increments in cell extrusion of $61.3,59.5,59.4$ and $66.9 \%$, compared with the estimates in the control (0 dS $\mathrm{m}^{-1}$ ), despite the decrease in electrolyte leakage as a function of the increment in Si levels. This may have occurred due to the increase in cell wall thickness and the strengthening of the membrane, promoted by the action of Si in the plant tissue (Lima et al., 2011).

The observed increase in electrolyte extrusion is associated with the effect of phytotoxicity of salts in plant organisms, due to the accumulation of ions in plant tissues (Silva et al., 2008). In addition, the disorders caused by this accumulation consist in modifications in the composition of membrane structures and cell organelles, which cause morphophysiological alterations in plants (Munns, 2005). These changes can cause increase in the rupture of cell membrane and consequent loss of its internal content.

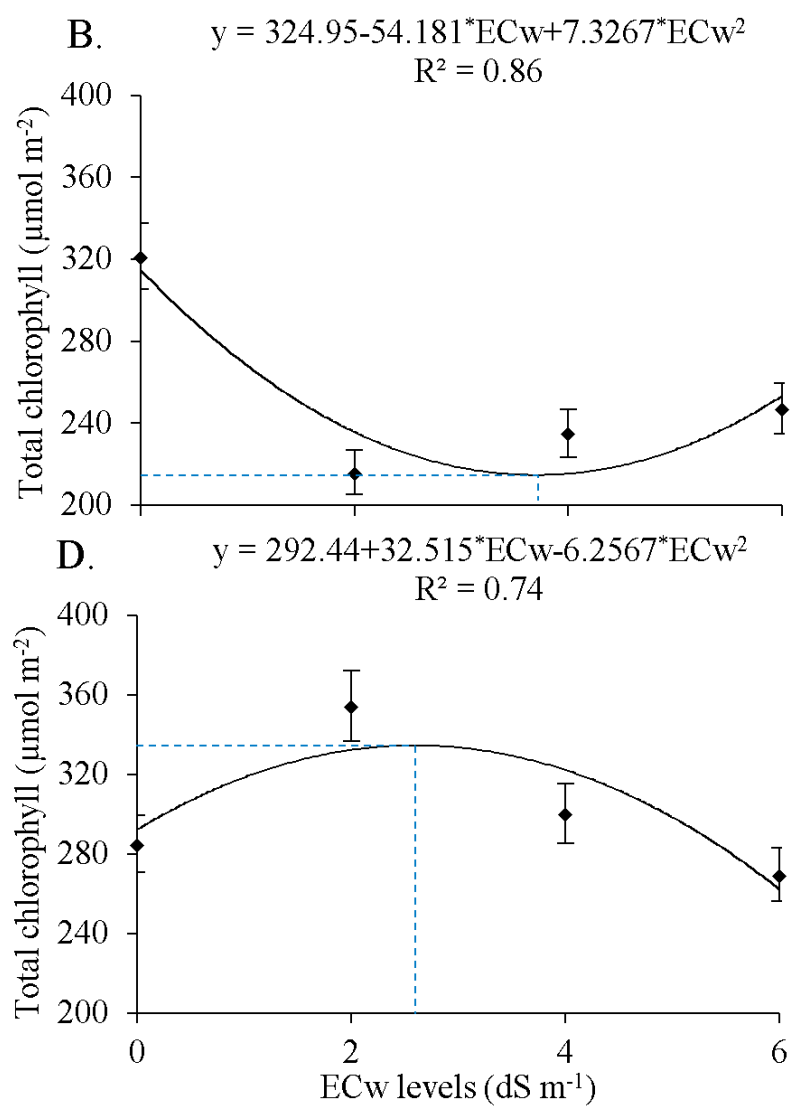

Figure 4. Effect of electrical conductivity of the irrigation water (ECw) at the silicon levels of 0 (A), 100 (B), 200 (C) and $300 \mathrm{mg} \mathrm{L}^{-1}$ (D) on the contents of total chlorophyll in leaves of the castor bean cultivar 'BRS Energia' cultivated in protected environment 

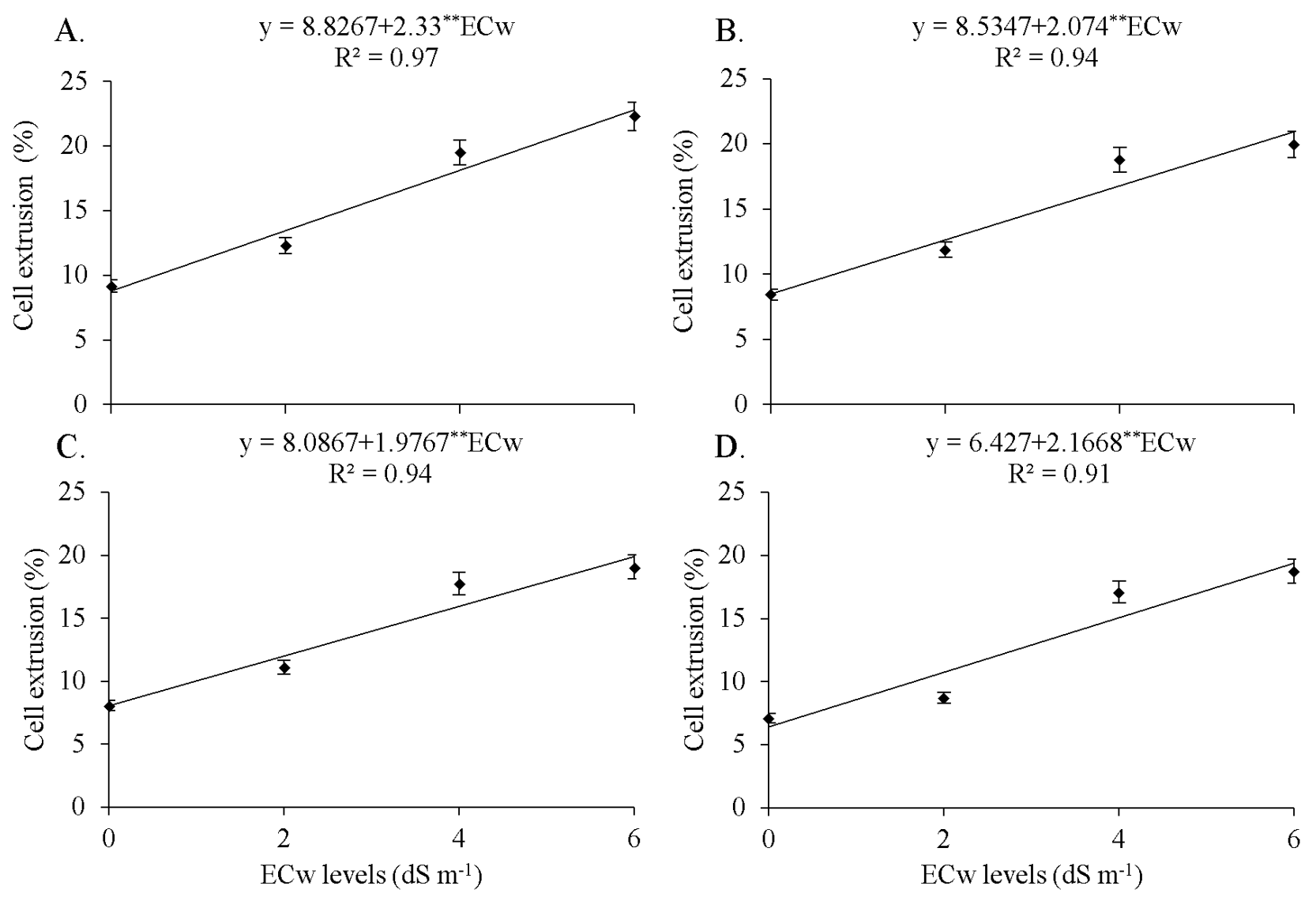

Figure 5. Effect of levels of electrical conductivity in the irrigation water (ECW) at the silicon levels of 0 (A), 100 (B), 200 (C) and $300 \mathrm{mg} \mathrm{L}^{-1}$ (D) on the cell extrusion (Ext) in leaves of the castor bean cultivar 'BRS Energia' cultivated in protected environment
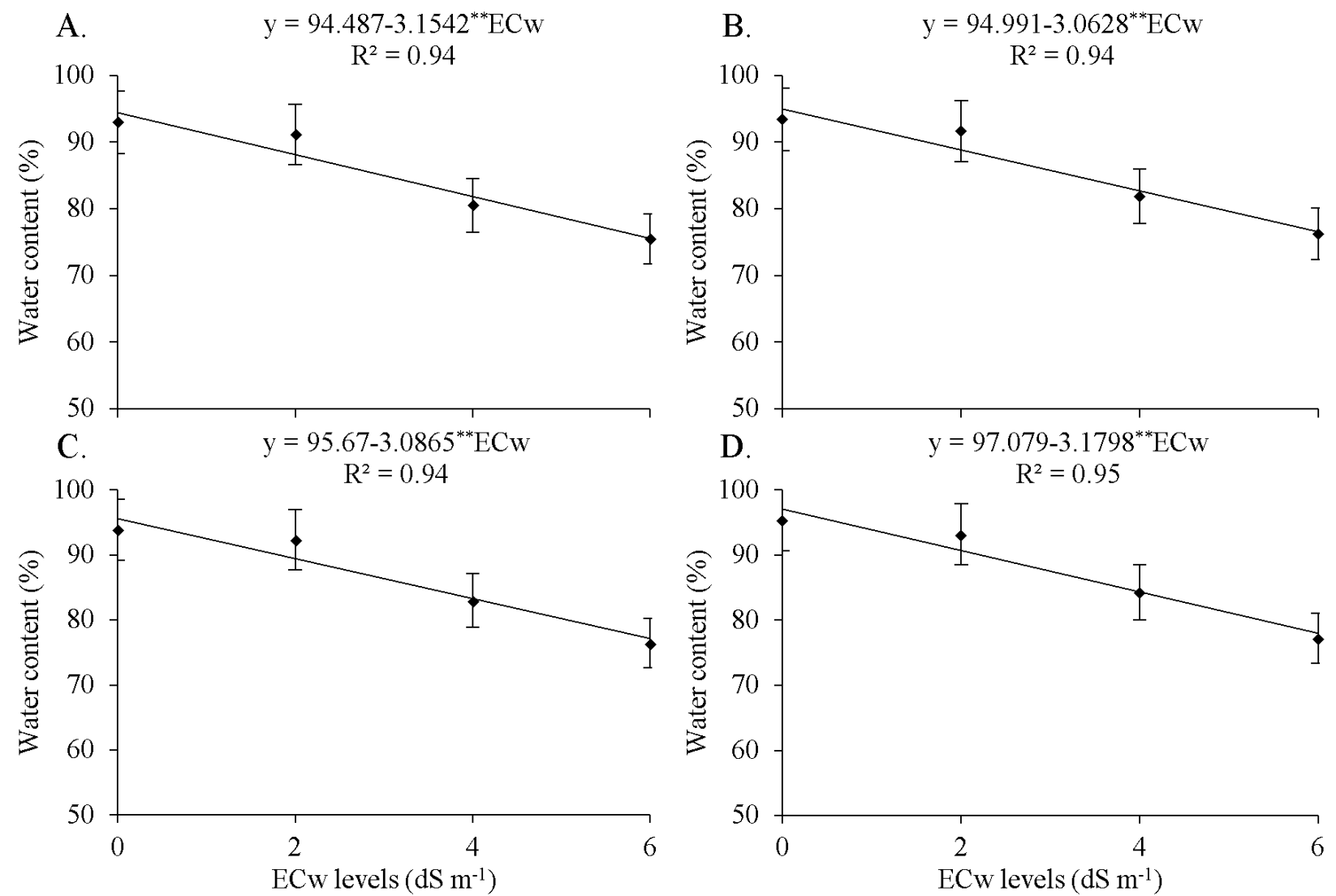

Figure 6. Effect of levels of electrical conductivity in the irrigation water (ECW) at the silicon levels of 0 (A), 100 (B), 200 (C) and $300 \mathrm{mg} \mathrm{L}^{-1}$ (D) on the relative water content of leaves of the castor bean cultivar 'BRS Energia' cultivated in protected environment 
The relative water content in the leaves (RWC) was significantly reduced $(\mathrm{p}<0.01)$ with the increase in the salinity levels of the irrigation water, and fitted the linear model. The most expressive estimates (94.5\% - Figure 6A; 95\% - Figure 6B; $95.7 \%$ - Figure 6C and 97\% - Figure 6D) were obtained in the treatment in which plants were not irrigated with saline water. On the other hand, RWC decreases of 20.1, 19.7, 19.6 and $19.5 \%$ were observed when compared with plants irrigated with $6 \mathrm{dS} \mathrm{m}^{-1}$ water. The decrease in RWC was attenuated with the increase in Si levels (Figure 6).

The depletion in RWC in the leaves must have occurred due to the osmotic effect of the salts in the substrate (Sousa et al., 2011), especially because of the reduction in soil water potential, which compromises water absorption by plants (Lobo et al., 2011). Thus, the lower reduction in RWC with higher Si levels must be related to its beneficial effect, which is due to the decrease in transpiration rate and consequent better use of water, resulted from the improvement in plant morphophysiological structure associated with the reduction of the osmotic effect of salts in the substrate, facilitating the absorption by the roots (Lima et al., 2011).

\section{Conclusions}

1. The increase in the saline concentration of the irrigation water promoted reduction in the contents of photosynthetic pigments and relative water content in the leaves, while increased cell membrane extrusion in the castor bean cultivar 'BRS Energia'.

2. Foliar application of silicon reduced the harmful effects of salts on the evaluated variables of the castor bean cultivar 'BRS Energia', under the studied conditions.

\section{ACKNowledgments}

The authors thank the Agricultural Sciences Graduate Program of the UEPB/Embrapa Cotton, the Coordination for the Improvement of Higher Education Personnel (CAPES), for granting the Master's scholarship to the first author and the Embrapa Cotton, for providing the infrastructure necessary for the conduction of this research.

\section{Literature Cited}

Al-Aghabary, K.; Zhu, Z.; Shi, Q. Influence of silicon supply on chlorophyll content, chlorophyll fluorescence, and antioxidative enzyme activities in tomato plants under salt stress. Journal of Plant Nutrition, v.27, p.2101-2115, 2005. http://dx.doi. org/10.1081/PLN-200034641

Arnon, D. I. Copper enzymes in isolated chloroplasts: Polyphenoloxydase in Beta vulgaris. Plant Physiology, v.24, p.115, 1949. http://dx.doi.org/10.1104/pp.24.1.1

Ávila, F. W.; Baliza, D. P.; Faquin, V.; Araújo, J. L.; Ramos, S. J. Interação entre silício e nitrogênio em arroz cultivado sob solução nutritiva. Revista Ciência Agronômica, v.41, p.184-190, 2010. http://dx.doi. org/10.1590/S1806-66902010000200003

Brito, G. G. de; Sofiati, V.; Lima, M. M. de A.; Carvalho, L. P. de; Silva Filho, J. L. da Physiological traits for drought phenotyping in cotton. Acta Scientiarum. Agronomy, v.33, p.117-125, 2011. http://dx.doi.org/10.4025/actasciagron.v33i1.9839
Chaves, L. H. G.; Gheyi, H. R.; Ribeiro, S. Consumo de água e eficiência do uso para cultivar de mamona Paraguaçu submetida à fertilização nitrogenada. Engenharia Ambiental, v.8, p.126-133, 2011.

Costa, F. X.; Beltrão, N. E. de M.; Melo Filho, J. S. de; Silva, D. P. da; Dantas, G. F; Silva, F. E. de A. Avaliação da fisiologia e bioquímica da mamoneira em função da aplicação de composto orgânico de lixo e torta de mamona como fertilizantes. Engenharia Ambiental, v.8, p.101-109, 2011.

Fagan, E. B.; Petter, S. L.; Simon, J.; Borcioni, E.; Luz, J. L. da; Manfron, P. A. Eficiência do uso de água do meloeiro hidropônico. Bioscience Journal, v.25, p.37-45, 2009.

Giongo, V.; Bohnen, H. Relação entre alumínio e silício em genótipos de milho resistente e sensível a toxidez de alumínio. Bioscience Journal, v.27, p.348-356, 2011.

Goneli, A. L. D.; Corrêa, P. C.; Magalhães, F. E. de A.; Baptestini, F. M. Contração volumétrica e forma dos frutos de mamona durante a secagem. Acta Scientiarum. Agronomy, v.33, p.1-8, 2011. http:// dx.doi.org/10.4025/actasciagron.v33i1.4629

Hiscox, J. D.; Israelstam, G. F. A method for the extraction of chlorophyll from leaf tissue without maceration. Canadian Journal of Botany, v.57, p.1332-1334, 1979. http://dx.doi.org/10.1139/b79-163

Lima, M. de A.; Castro, V. F. de; Vidal, J. B.; Enéas Filho, J. Aplicação de silício em milho e feijão-de-corda sob estresse salino. Revista Ciência Agronômica, v.42, p.398-403, 2011. http://dx.doi. org/10.1590/S1806-66902011000200019

Lobo, A. K. M.; Martins, M. de O.; Lima Neto, M. C.; Bonifácio, A.; Silveira, J. A. G. da. Compostos nitrogenados e carboidratos em sorgo submetido à salinidade e combinações de nitrato e amônio. Revista Ciência Agronômica, v.42, p.390-397, 2011. http://dx.doi. org/10.1590/S1806-66902011000200018

Lopes, K. P.; Silva, M. Salinidade na germinação de sementes de algodão colorido. Revista Verde de Agroecologia e Desenvolvimento Sustentável, v.5, p.274-279, 2010.

Marques, E. C.; Freitas, V. S.; Bezerra, M. A.; Prisco, J. T.; Gomes Filho, E. Efeitos do estresse salino na germinação, emergência e estabelecimento da plântula de cajueiro anão precoce. Revista Ciência Agronômica, v.42, p.993-999, 2011. http://dx.doi. org/10.1590/S1806-66902011000400023

Monteiro, A. L. N.; Montenegro, A. A. de A.; Montenegro, S. N. G.; Santos, F. X. dos. Avaliação de lavagem parcial de sais em neossolo flúvico irrigado, utilizando modelagem computacional. Engenharia Agrícola, v.29, p.207-220, 2009. http://dx.doi. org/10.1590/S0100-69162009000200004

Munns, R. Genes and salt tolerance: bringing them together. New Phytologist, v.167, p.645-663, 2005. http://dx.doi.org/10.1111/ j.1469-8137.2005.01487.x

Nazareno, A. C.; Afférri, F. S.; Peluzio, J. M.; Cancellier, L. P.; Leão, F. F.; Naoe, L. K. Avaliação de cultivares de mamona em três ambientes, no estado do Tocantins, safra 2007/2008. Bioscience Journal, v.27, p.297-304, 2011.

Oliveira, E. M. Avaliação do teor de óleo e peso em sementes de mamona utilizando diversos acessos. Engenharia Ambiental, v.8, p.205-211, 2011.

Peixoto, M. L.; Moraes, J. C.; Silva, A. A.; Assis, F. A. Efeito do silício na preferência para oviposição de Bemisia tabaci biotipo b (genn.) (hemiptera: aleyrodidae) em plantas de feijão (Phaseolus vulgaris L.). Ciência e Agrotecnologia, v.35, p.478-481, 2011. http://dx.doi. org/10.1590/S1413-70542011000300006 
Rodrigues, C. R. F.; Silva, E. V.; Silva, S. L. F.; Voigt, E. L.; Viégas, R. A.; Silveira, J. A. G. High $\mathrm{K}^{+}$supply avoids $\mathrm{Na}^{+}$toxicity and improves photosynthesis by allowing favorable $\mathrm{K}^{+}: \mathrm{Na}^{+}$ratios through the inhibition of $\mathrm{Na}^{+}$uptake and transport to the shoots of Jatropha curcas plants. Journal of Plant Nutrition and Soil Science, v.176, p.157-164, 2013. http://dx.doi.org/10.1002/ jpln.201200230

Sampaio Filho, O. M.; Silva, S. A.; Bahia, H. F.; Silva, M. S. da; Carvalho, D. dos S. Análise descritiva de cultivares de mamoneira em dois anos de cultivo no recôncavo baiano. Revista Brasileira de Educação Ambiental, v.6, p.28-34, 2011.

Santos, H. G.; Jacomine, P. K. T.; Anjos, L. H. C. dos; Oliveira, V. A. de; Oliveira, J. B. de; Coelho, M. R.; Lumbreras, J. F.; Cunha, T. J. F. Sistema brasileiro de classificação de solos. 2.ed. Rio de Janeiro: Embrapa Solos, 2006. 306p.

Santos, J. W. dos; Almeida, F. de A. C.; Beltrão, N. E. de M.; Cavalcanti, F. V. Estatística Experimental Aplicada. Campina Grande: Embrapa Algodão/UFCG, 2008. 461p.
Sávio, S. L.; Silva, G. C. da; Teixeira, I. R.; Borém, A. Produção de biomassa e conteúdo de silício em gramíneas forrageiras sob diferentes fontes de silicato. Semina: Ciências Agrárias, v.32, p.103110, 2011. http://dx.doi.org/10.5433/1679-0359.2011v32n1p103

Silva, G. F.; Oliveira, G. dos S.; Nascimento, J. J. V. R. do; Pereira, R. G.; Paiva, M. R. de F. C. Germinação e crescimento inicial de mamoneiras irrigadas com água salina em diferentes volumes de substrato. Revista Verde de Agroecologia e Desenvolvimento Sustentável, v.6, p.135-142, 2011.

Silva, S. M. S.; Alves, A. N.; Gheyi, H. R.; Beltrão, N. E. de M.; Severino, L. S.; Soares, S. A. L. Desenvolvimento e produção de duas cultivares de mamoneira sob estresse salino. Revista Brasileira de Engenharia Agrícola e Ambiental, v.12, p.335-342, 2008. http:// dx.doi.org/10.1590/S1415-43662008000400001

Sousa, A. E. C.; Gheyi, H. R.; Correia, K. G.; Soares, F. A. L.; Nobre, R. G. Crescimento e consumo hídrico de pinhão manso sob estresse salino e doses de fósforo. Revista Ciência Agronômica, v.42, p.310318, 2011. http://dx.doi.org/10.1590/S1806-66902011000200008 